\title{
Ocean acidification affects iron speciation during a coastal seawater mesocosm experiment
}

\author{
E. Breitbarth ${ }^{1,2}$, R. J. Bellerby ${ }^{1}$, C. C. Neill ${ }^{1}$, M. V. Ardelan $^{3}$, M. Meyerhöfer ${ }^{4}$, E. Zöllner ${ }^{4}$, P. L. Croot ${ }^{4}$, and \\ U. Riebesell ${ }^{4}$ \\ ${ }^{1}$ Bjerknes Centre for Climate Research, University of Bergen, Bergen, Allégaten 55, 5007 Bergen, Norway \\ ${ }^{2}$ Department of Chemistry, University of Otago, P.O. Box 56, Dunedin 9054, New Zealand \\ ${ }^{3}$ Norwegian University of Science and Technology, Department of Chemistry, 7491 Trondheim, Norway \\ ${ }^{4}$ Leibniz Institute of Marine Sciences (IFM-GEOMAR), Düsternbrooker Weg 20, 24105 Kiel, Germany
}

Received: 31 May 2009 - Published in Biogeosciences Discuss.: 9 July 2009

Revised: 8 February 2010 - Accepted: 16 February 2010 - Published: 19 March 2010

\begin{abstract}
Rising atmospheric $\mathrm{CO}_{2}$ is acidifying the surface ocean, a process which is expected to greatly influence the chemistry and biology of the future ocean. Following the development of iron-replete phytoplankton blooms in a coastal mesocosm experiment at 350, 700, and $1050 \mu$ atm $p \mathrm{CO}_{2}$, we observed significant increases in dissolved iron concentrations, $\mathrm{Fe}$ (II) concentrations, and $\mathrm{Fe}$ (II) half-life times during and after the peak of blooms in response to $\mathrm{CO}_{2}$ enrichment and concomitant lowering of $\mathrm{pH}$, suggesting increased iron bioavailability. If applicable to the open ocean this may provide a negative feedback mechanism to the rising atmospheric $\mathrm{CO}_{2}$ by stimulating marine primary production.
\end{abstract}

\section{Introduction}

Paleoclimate data indicate significant effects from the deposition of iron in aeolian dust on ocean biogeochemistry with feedbacks on global climate (Watson et al., 2000). Studies of artificial and natural iron input have demonstrated iron control of phytoplankton productivity and $\mathrm{CO}_{2}$ drawdown over vast oceanic regions (Boyd et al., 2007; Blain et al., 2007; Pollard et al., 2009) and in coastal upwelling regions (Bruland et al., 2001; Hutchins and Bruland, 1998). Temporal control of iron on phytoplankton productivity was also observed in a Norwegian fjord system (Öztürk et al., 2002).

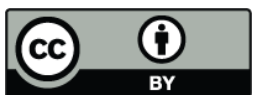

Correspondence to: E. Breitbarth (ebreitbarth@chemistry.otago.ac.nz)
Iron solubility in surface seawater is low, ranging in the picomolar and low nanomolar levels depending on temperature, and the speciation is largely controlled by organic complexation and photochemical redox processes (Kuma et al., 1996; Sunda and Huntsman, 2003; Kuma et al., 1992; Liu and Millero, 2002). In addition to iron binding organic compounds such as humic and fulvic acids that are generally present in coastal seawater, phytoplankton blooms can affect $\mathrm{Fe}(\mathrm{III})$-complexation, which affects the dissolved $\mathrm{Fe}$ fraction and photoreactivity (Croot et al., 2001; Kuma et al., 1992; Rue and Bruland, 1995). Ligand production is generally facilitated via zooplankton and protist grazing, microbial production, and potentially also by phytoplankton cell degradation (Heldal et al., 1996; Barbeau et al., 1996; Hutchins and Bruland, 1994). In return, iron bioavailability to prokaryotic or eukaryotic phytoplankton differs among types of organic iron complexation, such as chelation by siderophores or porphyrins (Hutchins et al., 1999). Fe(III)-complexation is interlinked with $\mathrm{Fe}(\mathrm{II})$ production in marine water, mainly via supplying a substrate for photoreduction in sunlit surface waters (Kuma et al., 1992; Öztürk et al., 2004; Barbeau et al., 2001, 2003). Other sources of Fe(II) include reduction of colloidal Fe (Wells and Mayer, 1991; Johnson et al., 1994; Rijkenberg et al., 2005), biological Fe(III) reduction (e.g. Maldonado and Price, 2001; Shaked et al., 2004), and suboxic and anoxic deep water as well as sediments (Hopkinson and Barbeau, 2007; Moffett et al., 2007; Breitbarth et al., 2009; Hansard et al., 2009).

$\mathrm{Fe}(\mathrm{II})$ is generally considered bioavailable but rapid reoxidation to $\mathrm{Fe}(\mathrm{III})$ in temperate and tropical waters results in limited concentrations of Fe(II). Half-life times of Fe(II)

Published by Copernicus Publications on behalf of the European Geosciences Union. 
range in the order of minutes and are largely dependent on temperature, oxygen and hydrogen peroxide concentrations, and pH (Santana-Casiano et al., 2005; Millero et al., 1987; Millero and Sotolongo, 1989), with presently limited knowledge about the role of organic $\mathrm{Fe}$ (II) complexation in natural seawater. However, the contribution of Fe(II) to phytoplankton nutrition may be significant in the open ocean (Roy et al., 2008), continental shelf waters (Ussher et al., 2007), as well as in estuarine waters (Breitbarth et al., 2009).

Despite our growing knowledge of iron biogeochemistry in seawater, we currently have little information on the effects of ocean acidification thereon. Seawater $\mathrm{pH}$ affects phytoplankton physiology (Fu et al., 2008; Hare et al., 2008; Riebesell, 2004) and thus indirect effects via phytoplankton exudates that complex iron may also alter biological influences on iron solubility and cycling. Further, the photoreduction of organic Fe-ligand complexes is an important pathway for $\mathrm{Fe}(\mathrm{II})$ production in the euphotic zone (King et al., 1993) and moreover $\mathrm{Fe}(\mathrm{II})$ oxidation rates are strongly $\mathrm{pH}$ dependent (e.g. Santana-Casiano et al., 2005). Based on estimates of unabated $\mathrm{CO}_{2}$ emissions, oceanic uptake of anthropogenic $\mathrm{CO}_{2}$ will lower surface ocean $\mathrm{pH}$ from a pre-industrial 8.25 to an estimated 7.85 within this century, and further by up to 0.7 units by 2300 (Caldeira and Wickett, 2003; Jacobson, 2005). This change far exceeds any glacial-interglacial differences (Caldeira and Wickett, 2003) and thus may have profound effects on the biogeochemistry of iron in seawater.

The Pelagic Ecosystem $\mathrm{CO}_{2}$ Enrichment Study (PeECE III) studied natural phytoplankton blooms under atmospheric $\mathrm{CO}_{2}$ scenarios of 350,700 , and $1050 \mu$ atm $p \mathrm{CO}_{2}$ in a coastal mesocosm experiment (Schulz et al., 2008). We used this unique opportunity to study iron chemistry in phytoplankton blooms grown simultaneously at different partial pressures of $\mathrm{CO}_{2}$. We particularly measured dissolved iron concentrations, as well as $\mathrm{Fe}$ (II) levels and oxidation rates over the course of the PeECE III mesocosm study to determine if ocean acidification may affect iron speciation in seawater.

\section{Methods}

The experimental work was carried out from 15 May through 9 June 2005 at the National Mesocosm Facility located at the Espeland Marine Biological Station at the Raunefjord $\left(60.3^{\circ} \mathrm{N}, 5.2^{\circ} \mathrm{E}\right)$, University of Bergen, Norway. Nine polyethylene (PE) enclosures $(2 \mathrm{~m}$ diameter, $10 \mathrm{~m}$ deep, hereafter called mesocosms), were moored to a raft about $200 \mathrm{~m}$ from shore. The enclosures were filled simultaneously by pumping unfiltered fjord water from $13.5 \mathrm{~m}$ depth. The mesocosms were capped with gastight and light transparent (95\% UV permeability) tents. Atmospheric $\mathrm{CO}_{2}$ concentrations within three mesocosms each were adjusted to 350,700 , and $1050 \mu \mathrm{atm} p \mathrm{CO}_{2}$. The water was bubbled at target $\mathrm{CO}_{2}$ until equilibrium was reached ( $\sim 2$ days). Phytoplankton blooms were initiated with $\mathrm{NaNO}_{3}$ and $\mathrm{Na}_{2} \mathrm{HPO}_{4}$ additions to target concentrations of 16 and $0.8 \mu \mathrm{mol} \mathrm{kg}-1$. Daily samples for all parameters except for trace metals, trace gases, dissolved inorganic carbon (DIC), and alkalinity were taken as a bulk sample using a $5 \mathrm{~m}$ long, $\sim 6 \mathrm{~cm}$ diameter flexible plastic tube to obtain depth integrated values. The $\mathrm{pH}$ values are calculated based on daily measurements of total alkalinity (TA) and dissolved inorganic carbon (DIC) in the mesocosm upper mixed layer and are expressed on the total $\mathrm{pH}$ scale. TA was measured using the classical Gran electrotitration method (Gran, 1952) (precision $\pm 4 \mu \mathrm{mol} \mathrm{kg}{ }^{-1}$ ). DIC was measured by coulometric titration (Johnson et al., 1987) with a precision of $2 \mu \mathrm{mol} \mathrm{kg}{ }^{-1}$. Chl- $a$ concentrations were determined using HPLC (Barlow et al., 1997) and particulate organic carbon (POC) was measured on an elemental analyzer (EuroEA 3000, EuroVector) (Ehrhard and Koeve, 1999). Please see Schulz et al. (2008) for more details about the experimental set-up of the PeECE III study and its general experimental outcome, as well as Engel et al. (2005) for a specific description of the mesocosm design and $\mathrm{CO}_{2}$ perturbation technique used.

Fe samples were obtained from $2.5 \mathrm{~m}$ depth through PTFE tubing using a PE syringe and passed into $50 \mathrm{~mL}$ PE vials using a 3-way valve, which allowed for flushing the sampling line by pumping mesocosm water to waste prior to each sampling. The valve and sampling port were protected by plastic bags (Minigrip) at all times. The filled vials were immediately bagged and transported to the lab, where further handling and filtration took place inside a class-100 laminar flow bench. Filtration for dissolved iron analysis was performed using a PTFE vacuum filtration unit and $45 \mathrm{~mm}$ $0.2 \mu \mathrm{m}$ polycarbonate membranes (Whatman). All filters, sampling and filtration equipment were trace metal cleaned by washing with $\mathrm{HCl}\left(1 \mathrm{~mol} \mathrm{~L}^{-1}\right)$ and subsequent high purity water (MilliQ) rinses and protected by double bags (Minigrip) for storage and transport. Exposure of the sampling equipment to outside air was kept to the absolute minimum time necessary to perform the sampling at the mesocosms.

Total unfiltered iron ( $\mathrm{tFe}$ ) and dissolved iron $(\mathrm{dFe}, 0.2 \mu \mathrm{m}$ filtered) measurements were conducted using chemiluminescence flow injection analysis (CL-FIA) (Bowie et al., 1998) using a commercially available CL-FIA instrument (Waterville Analytical, USA) and focused on the period of strong bloom development and $\mathrm{pH}$ shifts (days 7-13) and a post bloom measurement (day 23). The instrument was equipped with a $50 \mathrm{~cm}(1.2 \mathrm{~mL})$ sample loop and no sample preconcentration steps were applied. All reagents used were of high purity (Fluka, trace select or trace select ultra for $\mathrm{HCl}$ and $\mathrm{NH}_{3}$; Sigma BioUltra for $\mathrm{Na}_{2} \mathrm{SO}_{3}$; Sigma Ultra for $\mathrm{Na}_{2} \mathrm{CO}_{3}$ ), with the exception of Luminol (Sigma BioChemika). Purified water (Millipore, MilliQ) was used for all reagent preparations. Calibrations were done using standard additions. A $10 \mathrm{mmol} \mathrm{L}^{-1}$ primary $\mathrm{Fe}(\mathrm{II})$ standard solution was prepared from a Merck Titrisol Fe(II) standard in $0.1 \mathrm{~mol} \mathrm{~L}^{-1} \mathrm{HCl}$. Secondary standards were prepared immediately prior to use by serial dilution of the primary standard 


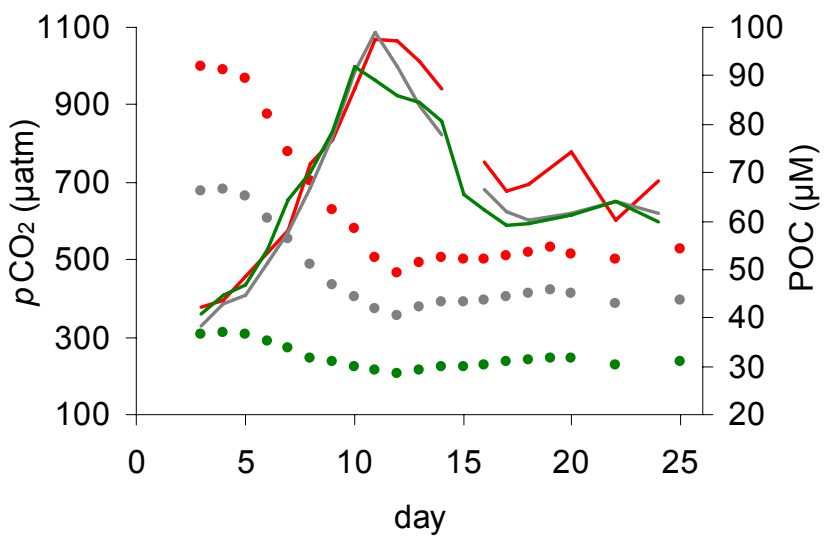

Fig. 1. Development of $p \mathrm{CO}_{2}$ (dots) and POC (lines) over the course of the mesocosm experiment shown as the mean values of the high (red), mid (grey), and low $\mathrm{CO}_{2}$ (green) treatments. See Schulz et al. (2008) for the complete data set.

using $0.01 \mathrm{~mol} \mathrm{~L}^{-1} \mathrm{HCl}$. All standard additions were kept below $0.1 \%$ volume to reduce the effect of lowering the sample $\mathrm{pH}$ to a minimum.

Fe(II) was determined based on Croot and Laan (2002) using the same CL-FIA instrument and reagents. For this purpose the instrument was installed inside an instrument shack on the mesocosm raft during days 20 and 22 of the experiment. Similar to the total and dissolved Fe samples, water was collected from $2.5 \mathrm{~m}$ depth through PTFE tubing using a PE syringe, which here was immediately followed by $0.2 \mu \mathrm{m}$ filtration (Whatman polycarbonate membrane) from the collection syringe and injection into the CL-FIA system. The exact time that had passed between sampling and injection into the analyzer was noted and the chemiluminescent signal decay was fitted to an exponential function, which allowed calculation of the $\mathrm{Fe}$ (II) concentration at the time of sampling. The Naperian log transformed chemiluminescent signals over time of five successive analysis cycles yield a linear signal decrease and the slope represents the $\mathrm{Fe}(\mathrm{II})$ oxidation rate constant $\left(k_{\mathrm{ox}} \mathrm{s}^{-1}\right)$. Predicted $\mathrm{Fe}(\mathrm{II})$ oxidation rates were further calculated based on Millero et al. (1987) after calculating the $\left[\mathrm{OH}^{-}\right]$concentration of the water using the $\mathrm{CO}_{2}$ SYS program (Lewis and Wallace, 1998), taking seawater carbonate chemistry measurements and oxygen concentrations into account. Fe(II) calibration curves were obtained using standard additions on seawater sampled from the respective mesocosms that was aged to allow oxidation of any $\mathrm{Fe}(\mathrm{II})$ present.

\section{Results and discussion}

$\mathrm{CO}_{2}$ perturbation and phytoplankton bloom development resulted in $\mathrm{pH}$ values of 7.67-7.97, 7.82-8.06, and 8.13-8.26 at 1050,700 , and $350 \mu \mathrm{atm} p \mathrm{CO}_{2}$, respectively during days 3-12 and relatively constant levels thereafter (Figs. 1 and

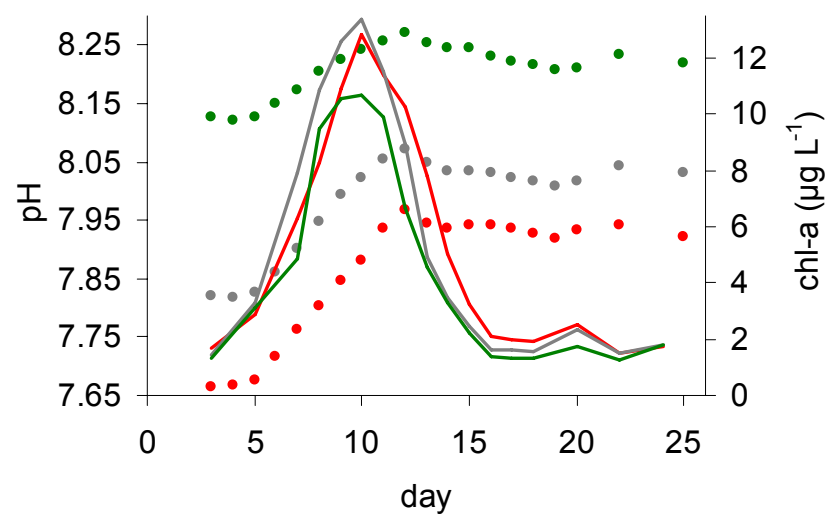

Fig. 2. Development of $\mathrm{pH}$ (dots) and Chl- $a$ (lines) over the course of the mesocosm experiment shown as the mean values of the high (red), mid (grey), and low $\mathrm{CO}_{2}$ (green) treatments. See Schulz et al. (2008) for the complete data set.

2). The peak of the bloom was marked by Chl- $a$ concentrations at days 9 (low $\mathrm{CO}_{2}$ ) and 10 (mid and high $\mathrm{CO}_{2}$ ) and resulted in particulate organic carbon (POC) concentrations that peaked at days 10 (low $\left.\mathrm{CO}_{2}, 91.9 \mu \mathrm{mol} \mathrm{L}^{-1}\right)$ and 11 (mid and high $\mathrm{CO}_{2}, 98.9$ and $97.4 \mu \mathrm{mol} \mathrm{L}{ }^{-1}$ respectively) (Figs. 1 and 2). Seawater temperature increased over the course of the study from $9.5^{\circ} \mathrm{C}$, peaked at $11.6^{\circ} \mathrm{C}$ on day 20 and decreased again to $10.4^{\circ} \mathrm{C}$ on day 25 , with a most rapid increase from $9.9-11.3^{\circ} \mathrm{C}$ between days 14 and 17 (Fig. 3). No significant difference in temperature was found between mesocosm enclosures. Temperature increased from initially $9.5^{\circ} \mathrm{C}$ to a peak of $11.6^{\circ} \mathrm{C}$ on day 20 , after which temperature dropped again to $10.4^{\circ} \mathrm{C}$ by day 25 (Fig. 3). In contrast, oxygen saturation, which ranged between 340 and $360 \mu \mathrm{mol} \mathrm{kg}{ }^{-1}$ on day 3 , dropped most prominently during the period of rapid temperature increase and reached lowest levels of $286-305 \mu \mathrm{mol} \mathrm{kg}{ }^{-1}$ on day 19 , with the high $\mathrm{CO}_{2}$ treatments showing elevated oxygen saturation overall (Fig. 3). See Schulz et al. (2008) for more details about the bloom development.

The Chl- $a$ and POC biomasses in the three $p \mathrm{CO}_{2}$ treatments are not markedly different. Nevertheless, our experiments show significantly higher dissolved iron $(<0.2 \mu \mathrm{m}$, $\mathrm{dFe}$ ) concentrations for high $\mathrm{CO}_{2}$ treatments in comparison to the mid- and low $\mathrm{CO}_{2}$ scenarios (e.g. 4.42 vs. 1.92 and $2.73 \mathrm{nmol} \mathrm{L}^{-1}$ on day 9, Fig. 4). During the bloom dFe decreased, which reflects iron uptake as well as cell surface and particle adsorption in all treatments. Remineralization during bloom decline increased $\mathrm{dFe}$ levels again and $\mathrm{dFe}$ was maintained at significantly higher levels in the future scenario compared to the mid and low $\mathrm{CO}_{2}$ treatments. Distinct differences between $\mathrm{dFe}$ concentrations towards the end of the bloom (day 23, 2.8-4.2 $\mathrm{nmol} \mathrm{L}^{-1}$ at low and mid $\mathrm{CO}_{2}, 6.0$ $8.2 \mathrm{nmol} \mathrm{L}^{-1}$ under high $\mathrm{CO}_{2}$, Fig. 4) suggest differences in $\mathrm{Fe}$ remineralization in the treatments. Fe concentrations in the mesocosms differ from nearby fjord water $\left(6.2 \mathrm{nmol} \mathrm{L}^{-1}\right.$ 


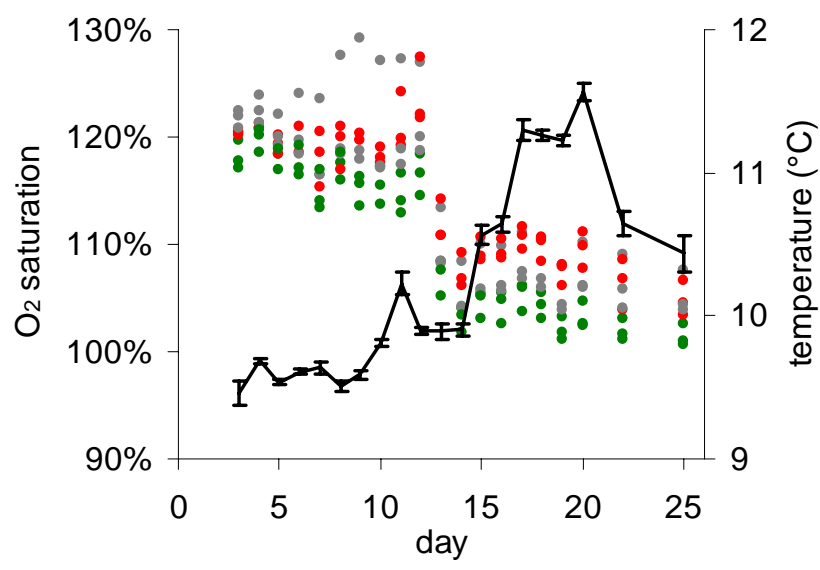

Fig. 3. Oxygen saturation and temperature as a function of time during the mesocosm experiment. For oxygen saturation: high $\mathrm{CO}_{2}=$ red, mid $\mathrm{CO}_{2}=$ grey, low $\mathrm{CO}_{2}=$ green. The relatively high oxygen saturation values in the mid $\mathrm{CO}_{2}$ treatment (day 5-12) originate from enclosure \#4, which was not used for the discrete Fe(II) samples discussed in this work. The overall mean temperatures of all nine enclosures are shown as a black line (error bars are standard deviations).

tFe and $3.0 \mathrm{nmol} \mathrm{L}^{-1} \mathrm{dFe}$ on day 13). However, the $\mathrm{dFe}$ values in the low and mid $\mathrm{CO}_{2}$ treatments at the peak of the bloom (1.9 and $2.7 \mathrm{nmol} \mathrm{L}^{-1}$, respectively) are slightly below concentrations in fjord water and also revert to values close to concentrations in the fjord by the end of the experiment $\left(3.5 \mathrm{nmol} \mathrm{L}^{-1}\right)$, while only the high $\mathrm{CO}_{2}$ treatment had systematically higher $\mathrm{dFe}$ concentrations.

Total Fe ranged from 23.7 to $96.1 \mathrm{nmol} \mathrm{L}^{-1}$ and varied between enclosures and over time. However, dissolved $\mathrm{Fe}$ values do not correlate with $\mathrm{tFe}$ and thus $\mathrm{tFe}$ concentrations are not responsible for the systematically increased $\mathrm{dFe}$ values in the high $\mathrm{CO}_{2}$ treatments (Fig. 5). The total Fe data suggest an input of particulate $\mathrm{Fe}$ into the mesocosms at an early stage of the study. During the filling process water was pumped from $13.5 \mathrm{~m}$, which most likely introduced particulate $\mathrm{Fe}$ from sediment sources. Though we acknowledge the need of development for trace metal clean studies in this field (Breitbarth et al., 2010) and we adhered to trace metal clean protocols during iron sampling, this large scaled experiment proved to be impossible to be fully carried out to such specifications. Clearly, the mesocosms were Fe-replete as they also would have been without any additional input of $\mathrm{Fe}$ to the experiment. While we lack iron measurements from the start of the experiment, applying an Fe:C ratio of $65 \mu \mathrm{mol}: \mathrm{mol}$ (Sarthou et al., 2005) yields an iron demand of $2-6 \mathrm{nmol} \mathrm{L}^{-1}$ during the bloom, which approximates iron concentrations detected in fjord water, as well as the changes in dissolved iron concentrations during the bloom. Our dFe data are clearly influenced by bloom development and we conclude that $\mathrm{dFe}$ was elevated as an effect of the mid and high $p \mathrm{CO}_{2}$ treatments.

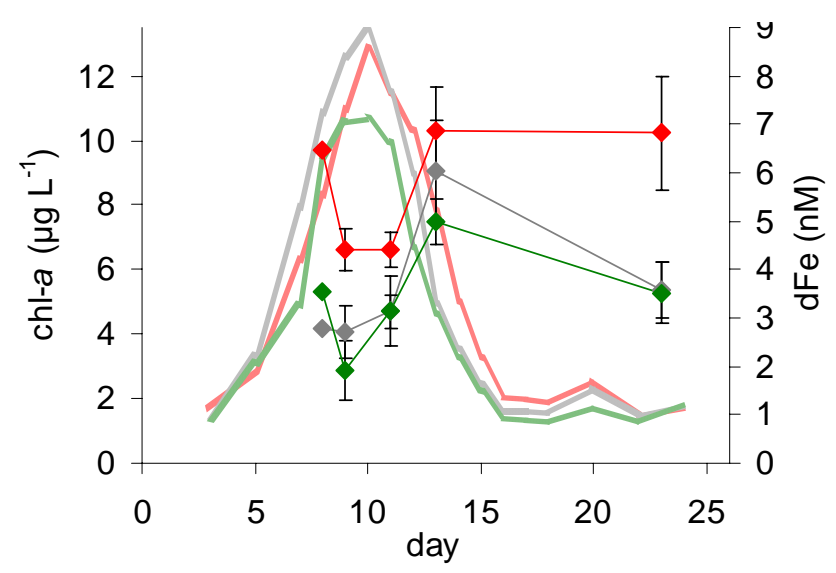

Fig. 4. Mean dFe concentrations (diamonds, error bars denote standard deviations, $n=3$ ) and mean Chl- $a$ concentrations (lines) during the mesocosm experiment at high (red), mid (grey), and low $\mathrm{CO}_{2}$ (green).

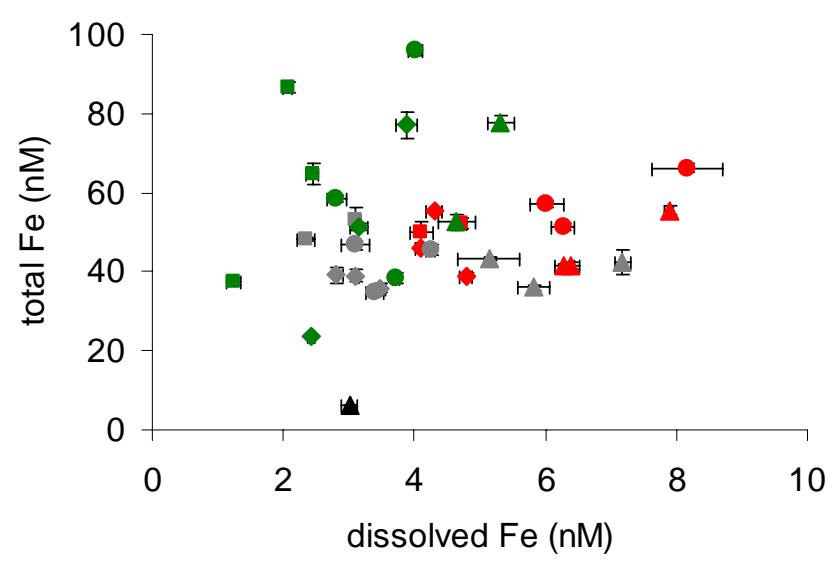

Fig. 5. $\mathrm{dFe}$ concentrations plotted versus tFe concentrations during the mesocosm experiment. High $\mathrm{CO}_{2}=$ red, mid $\mathrm{CO}_{2}=$ grey, low $\mathrm{CO}_{2}=$ green, fjord water=black. Squares=day 9, diamonds=day 11, triangles $=$ day 13 , circles=day 23 . Error bars denote precision of the analysis.

The predicted $\mathrm{Fe}(\mathrm{III})$-hydroxide solubility change over the observed $\mathrm{pH}$ ranges during the iron measurements (7.778.21 up to $7.94-8.26$, Fig. 2) is significantly lower than the observed differences in $\mathrm{dFe}$. Inorganic Fe solubility is strongly $\mathrm{pH}$ dependent, however in UV irradiated seawater at $25{ }^{\circ} \mathrm{C}$ iron solubilities between 0.3 and $0.44 \mathrm{nmol} \mathrm{L}^{-1}$ were measured (Liu and Millero, 2002; Kuma et al., 1996) with little change in the $\mathrm{pH}$ range of 7.8-8.6, making predictions of changes in our $\mathrm{pH}$ range difficult. Based on extensive measurements over a wider $\mathrm{pH}$ range from Liu and Millero (2002), Millero et al. (2009) suggest an increase in $\mathrm{Fe}$ solubility of $40 \%$ with a $\mathrm{pH}$ decrease from 8.1-7.4. Overall, these trends can not explain the increase in $\mathrm{dFe}$ at the nanomolar level (Fig. 4) observed in our study, suggesting that biological iron-ligand production and colloid formation 


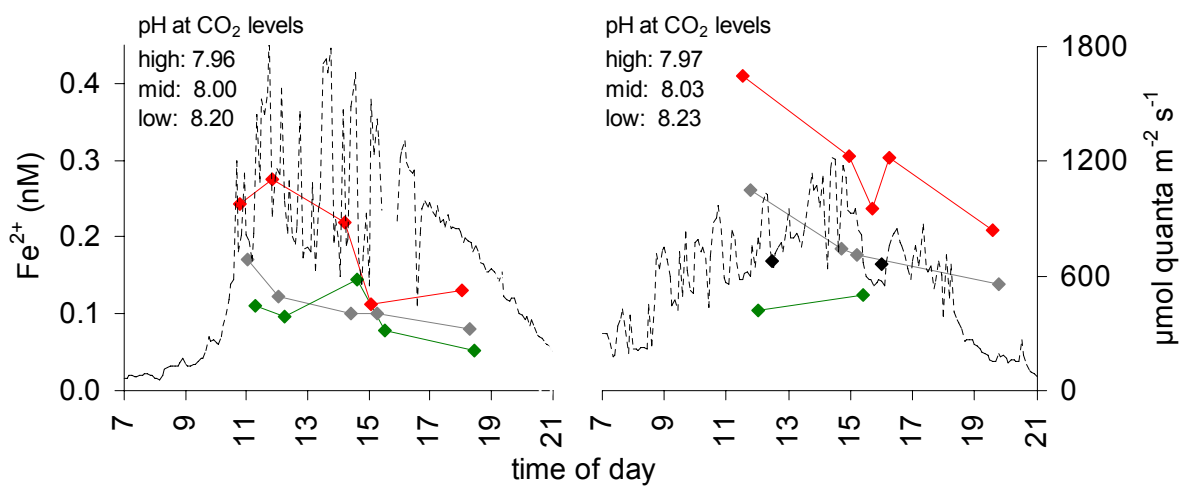

Fig. 6. $\mathrm{Fe}^{2+}$ at high (red), mid (grey), low $\mathrm{CO}_{2}$ (green), and in fjord water (black) and light intensity (photosynthetic active radiation (PAR), dotted line) during days 20 (left) and 22 (right).

in addition to $\mathrm{pH}$ dependence of iron chelation and iron hydroxide precipitation may be responsible for maintaining elevated dFe in the high $\mathrm{CO}_{2}$ mesocosms (Kuma et al., 1996; Millero, 1998; Sunda and Huntsman, 2003; Millero et al., 2009). We also can not fully rule out that $\mathrm{pH}$ effects on the dissolution of particulate $\mathrm{Fe}$ contributed to these trends, but considering the inorganic Fe solubility changes such an effect can not account for the increased $\mathrm{dFe}$ in the high $\mathrm{CO}_{2}$ treatments. Rue and Bruland (1997) demonstrated a 4-fold increase of iron binding ligands in response to iron addition in a iron depleted system during the Iron-Ex-II studies and infer positive effects thereof on the bioavailability of the added iron. Croot et al. (2001) show a $\sim 2$-fold Fe-ligand concentration increase resulting in rising $\mathrm{dFe}$ concentrations after 12-13 days iron induced phytoplankton bloom development. This was paralleled by a $\sim 5$-fold increase in chlorophyll-a biomass, similar to our study. Likewise, Croot et al. (2004) suggest a biological source of iron ligands in association with chlorophyll maxima in the water column. Colloidal and organically complexed $\mathrm{Fe}$ fractions were also associated with phytoplankton blooms in Norwegian coastal waters (Öztürk et al., 2002, 2003), and may further be controlled by bacterial production of extracellular matrixes (Heldal et al., 1996). All of the above further support the inclination that the increased $\mathrm{dFe}$ concentrations during the high $\mathrm{CO}_{2}$ treatments were at least in part biologically controlled.

The high $\mathrm{CO}_{2}$ mesocosms showed higher $\mathrm{Fe}(\mathrm{II})$ values compared to the lower $\mathrm{CO}_{2}$ treatments. Values between 52 and $411 \mathrm{pmol} \mathrm{L}^{-1}$ were detected, depending on treatment and time of day (Fig. 6). Elevated concentrations were measured during midday. Fast moving cloud cover however frequently obstructed irradiation for various periods of time (Fig. 6, photosynthetic active radiation data) and thus affected the midday pattern of a clear diel cycle in $\mathrm{Fe}$ (II) levels. The solubility of $\mathrm{Fe}$ (II) is significantly greater than for $\mathrm{Fe}(\mathrm{III})$ and at the low pH levels in the high $\mathrm{CO}_{2}$ mesocosms the oxidation rates of $\mathrm{Fe}$ (II) are much lower (Fig. 7), which may be the main process resulting in higher Fe(II) levels (Santana-
Casiano et al., 2006). Further, A pH decrease may affect iron-ligand complex stabilities, resulting in altered photolability of Fe(III)-ligand complexes (Lewis et al., 1995; Sunda and Huntsman, 2003). Also, reoxidation of $\mathrm{Fe}(\mathrm{II})$ to $\mathrm{Fe}(\mathrm{III})$ ' possibly will enhance the formation of Fe colloids, which may be reflected in the higher $\mathrm{dFe}$ concentrations in the high $\mathrm{CO}_{2}$ treatments.

Predictions of the Fe(II) half-lives over the course of the experiment reflect the expected $\mathrm{pH}$ dependence of $\mathrm{Fe}(\mathrm{II})$ oxidation rates (Fig. 7). The Fe(II) speciation shifts towards $\mathrm{Fe}^{2+}$ below $\mathrm{pH} 8.2$, however the oxidation rate is still largely controlled by the oxidation of $\mathrm{Fe}(\mathrm{OH})_{2}$ (Santana-Casiano et al., 2006; Millero et al., 1995). Bloom dynamics caused $\mathrm{pH}$ shifts in the treatments that result in a much broader range of predicted $\mathrm{Fe}(\mathrm{II})$ half-lives in the high $\mathrm{CO}_{2}$ treatments (3.420.6 min and 2.2-9.8 min, high and mid $\mathrm{CO}_{2}$, respectively) vs. the low $\mathrm{CO}_{2}$ treatment (1.1-2.6 min, Fig. 7). Especially during the early phase of the bloom, the relatively slow $\mathrm{Fe}(\mathrm{II})$ oxidation rates at low $\mathrm{pH}$ may increase the bioavailability of iron via allowing for a larger standing stock of $\mathrm{Fe}$ (II) in the high $\mathrm{CO}_{2}$ mesocosms. Falling oxygen concentrations with bloom decline and organic matter remineralization after day 12 (by $\sim 10 \%$ saturation overall) do not fully counteract acceleration effects on $\mathrm{Fe}(\mathrm{II})$ oxidation of the increasing temperature by $\sim 0.5^{\circ} \mathrm{C}$ each on days 15 and 17 (Fig. 3). The product of both effects is visible in the parallel shift of the oxidation rate and resulting half-life times towards the lower end of the $\mathrm{pH}$ range of each treatment (Fig. 7). It should be noted that the contribution of hydrogen peroxide is not considered here, but may have implications when concentrations exceed $200 \mathrm{nmol} \mathrm{L}^{-1}$, which is possible in coastal waters (Santana-Casiano et al., 2005). However, if hydrogen peroxide concentrations were sufficient to control $\mathrm{Fe}(\mathrm{II})$ oxidation rates then the actual measured oxidation rates should be faster than the predicted rates, which are based on oxidation by oxygen alone. The opposite is the case, arguing against a significant hydrogen peroxide contribution to $\mathrm{Fe}(\mathrm{II})$ oxidation rates during this study. Measured Fe(II) half life 
Table 1. Fe(II) oxidation rates and half lifes in the mesocosms during mid-day on day 20 and day 22 compared with Fe(II) oxidation rates estimated based on Millero et al. (1987). Measurements were performed at the same time as carbonate system measurements. See also Fig. 6 for the respective $\mathrm{Fe}(\mathrm{II})$ concentrations measured.

\begin{tabular}{|c|c|c|c|c|c|c|c|}
\hline \multirow[b]{2}{*}{ day } & \multicolumn{5}{|c|}{ measured } & \multicolumn{2}{|c|}{ predicted } \\
\hline & $\begin{array}{l}\mathrm{pH} \\
\text { total }\end{array}$ & $\begin{array}{c}T \\
\left({ }^{\circ} \mathrm{C}\right)\end{array}$ & $\left.\begin{array}{c}\mathrm{O}_{2} \\
(\mu \mathrm{mol} \mathrm{L} \\
-1\end{array}\right)$ & $\begin{array}{l}\log \mathrm{k}_{o x} \\
\left(\min ^{-1}\right)\end{array}$ & $\begin{array}{c}t 1 / 2 \\
(\min )\end{array}$ & $\begin{array}{c}\log k_{\mathrm{OX}} \\
\left(\min ^{-1}\right)\end{array}$ & $\begin{array}{l}t 1 / 2 \\
(\min )\end{array}$ \\
\hline 20 & 8.20 & 11.5 & 287.6 & -0.90 & 5.5 & -0.26 & 1.3 \\
\hline 20 & 8.00 & 11.6 & 297.1 & -1.21 & 11.2 & -0.64 & 3.0 \\
\hline 20 & 7.97 & 11.6 & 311.3 & -1.24 & 12.0 & -0.69 & 3.4 \\
\hline 22 & 8.23 & 10.5 & 291.2 & -0.96 & 6.3 & -0.31 & 1.4 \\
\hline 22 & 8.03 & 10.7 & 297.2 & -1.18 & 10.4 & -0.67 & 3.3 \\
\hline 22 & 7.98 & 10.6 & 305.4 & -1.21 & 11.2 & -0.78 & 4.2 \\
\hline
\end{tabular}

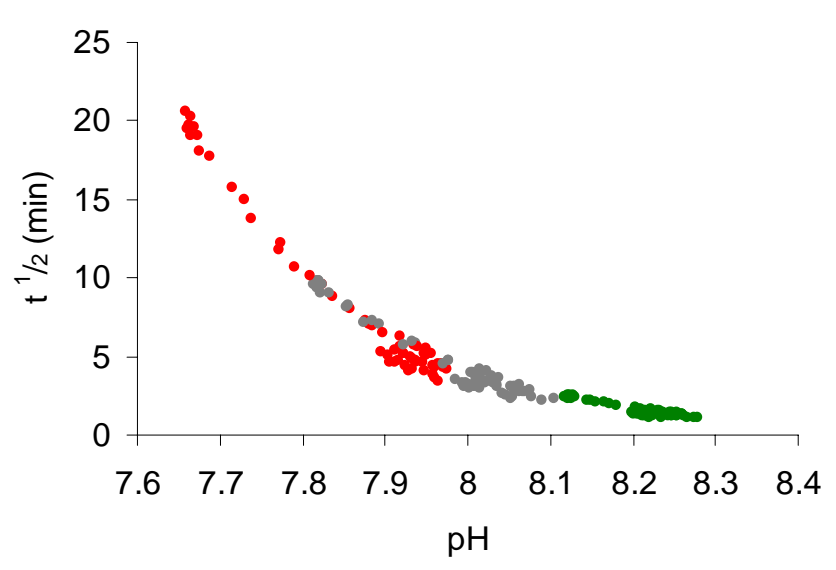

Fig. 7. Calculated theoretical estimates of $\mathrm{Fe}(\mathrm{II})$ half-life times as a function of actual $\mathrm{pH}$ values measured over the course of the mesocosm experiment. The Fe(II) half-life times were calculated based on Millero et al. (1987) using oxygen saturation and temperature data as shown in Fig. 7. The color shading refers to the $\mathrm{pH}$ data obtained from mesocosms at their respective $\mathrm{CO}_{2}$ treatments (high $\mathrm{CO}_{2}=$ red, mid $\mathrm{CO}_{2}=$ grey, low $\mathrm{CO}_{2}=$ green).

times range from 5.5-12 min, expectedly with highest values in the high $\mathrm{CO}_{2}$ treatments, and exceed predicted values by 2.6-4.5 times (Table 1).

While the $\mathrm{pH}$ effect on inorganic $\mathrm{Fe}(\mathrm{II})$ speciation and thus on Fe(II) oxidation rates is clearly evident, our data imply an additional influence of phytoplankton bloom derivates on the actual half-life times. Hydrocarboxylic acids, such as glucaric acid, affect photoreduction of Fe(III) and may be released from phytoplankton (Kuma et al., 1992; Öztürk et al., 2004) while their direct effect on Fe(II) oxidation remains to be shown. However, organic Fe(II) complexation and consequential effects on the lifetime of $\mathrm{Fe}(\mathrm{II})$ in seawater have been suggested previously (Croot et al., 2001, 2007; Breitbarth et al., 2009). Our data suggest two possible mechanisms tying into $\mathrm{Fe}(\mathrm{II})$ cycling at different $\mathrm{pH}$. Differences in oxidation rates and their deviation from the predicted rates possibly indicate organic $\mathrm{Fe}(\mathrm{II})$-complexation, which additionally may affect the Fe(II) half life in the low pH treatments stronger than in the high $\mathrm{pH}$ mesocosms. Furthermore, biologically mediated $\mathrm{Fe}(\mathrm{III})$-chelates supply the major pool of iron for photoreduction and this main $\mathrm{Fe}(\mathrm{II})$ production pathway in surface seawater (Boyd et al., 2000; Kuma et al., 1992) appears to operate more effectively at high $\mathrm{CO}_{2}$ allowing for the elevated $\mathrm{Fe}$ (II) concentrations detected in the future ocean treatments. This may be further enhanced by the photoreactivity of an increased Fe colloid pool (Johnson et al., 1994; Rijkenberg et al., 2005; Wells and Mayer, 1991) at lower seawater $\mathrm{pH}$. Effects thereof on biological production and remineralization may be profound.

Our study indicates that ocean acidification may lead to enhanced Fe-bioavailability due to an increased fraction of $\mathrm{dFe}$ and elevated $\mathrm{Fe}(\mathrm{II})$ concentrations in coastal systems. Such may be due to $\mathrm{pH}$ induced changes in organic iron complexation and $\mathrm{Fe}(\mathrm{II})$ oxidation rates. Overall this will result in increased turnover of $\mathrm{Fe}$ in surface seawater, potentially maintaining iron bioavailability given a sufficient supply of total $\mathrm{Fe}$, since equilibrium partitioning eventually restores the biolabile Fe pools that have been depleted by biological uptake. These processes may further fuel increased phytoplankton carbon acquisition and export at future atmospheric $\mathrm{CO}_{2}$ levels (Riebesell et al., 2007). Provided that the observed $\mathrm{CO}_{2}$ sensitivity of iron chemistry represents a general phenomenon operating also in phytoplankton blooms of oceanic areas, it could have a profound effect on productivity in the future ocean (Blain et al., 2007; Boyd et al., 2007). Our results support the notion that changes in iron speciation and the resulting potential negative feedback mechanism of phytoplankton productivity on atmospheric $\mathrm{CO}_{2}$ need to be considered when assessing the ecological effects of ocean acidification. 
Acknowledgements. We gratefully acknowledge the help received from the staff of the Espeland Marine Biological Station, University of Bergen, Norway during the study. This work was partially funded through the MERCLIM project "Marine Ecosystem Response to a Changing Climate" (Norwegian Research Foundation (NFR), contract no. 184860/S30) and the University of Bergen LOCUS project. We further thank P. W. Boyd for his comments on an earlier version of the manuscript. E. B. especially thanks A. Aadnesen, as well as M. Hassellöv and D. R. Turner for their support and acknowledges current funding by the German Research Foundation (DFG, BR 3794). The initial manuscript was greatly improved by the reviews of W. Sunda and two anonymous colleagues.

Edited by: D. Turner

\section{References}

Barbeau, K., Moffett, J. W., Caron, D. A., Croot, P. L., and Erdner, D. L.: Role of protozoan grazing in relieving iron limitation of phytoplankton, Nature, 380, 61-64, 1996.

Barbeau, K., Rue, E. L., Bruland, K. W., and Butler, A.: Photochemical cycling of iron in the surface ocean mediated by microbial iron(III)-binding ligands, Nature, 413, 409-413, 2001.

Barbeau, K., Rue, E. L., Trick, C. G., Bruland, K. T., and Butler, A.: Photochemical reactivity of siderophores produced by marine heterotrophic bacteria and cyanobacteria based on characteristic Fe(III) binding groups, Limnol. Oceanogr., 48, 1069-1078, 2003.

Barlow, R. G., Cummings, D. G., and Gibb, S. W.: Improved resolution of mono- and divinyl chlorophylls $\mathrm{a}$ and $\mathrm{b}$ and zeaxanthin and lutein in phytoplankton extracts using reverse phase C-8 HPLC, Mar. Ecol. Prog. Ser., 161, 303-307, 1997.

Blain, S., Queguiner, B., Armand, L., Belviso, S., Bombled, B., Bopp, L., Bowie, A., Brunet, C., Brussaard, C., Carlotti, F., Christaki, U., Corbiere, A., Durand, I., Ebersbach, F., Fuda, J.-L., Garcia, N., Gerringa, L., Griffiths, B., Guigue, C., Guillerm, C., Jacquet, S., Jeandel, C., Laan, P., Lefevre, D., Lo Monaco, C., Malits, A., Mosseri, J., Obernosterer, I., Park, Y.-H., Picheral, M., Pondaven, P., Remenyi, T., Sandroni, V., Sarthou, G., Savoye, N., Scouarnec, L., Souhaut, M., Thuiller, D., Timmermans, K., Trull, T., Uitz, J., van Beek, P., Veldhuis, M., Vincent, D., Viollier, E., Vong, L., and Wagener, T.: Effect of natural iron fertilization on carbon sequestration in the Southern Ocean, Nature, 446, 1070-1074, 2007.

Bowie, A. R., Achterberg, E. P., Mantoura, R. F. C., and Worsfold, P. J.: Determination of sub-nanomolar levels of iron in seawater using flow injection with chemiluminescence detection, Anal. Chim. Acta, 361, 189-200, 1998.

Boyd, P. W., Watson, A. J., Law, C. S., and Abraham, E. R.: A mesoscale phytoplankton bloom in the polar Southern Ocean stimulated by iron fertilization, Nature, 407, 695-702, 2000.

Boyd, P. W., Jickells, T., Law, C. S., Blain, S., Boyle, E. A., Buesseler, K. O., Coale, K. H., Cullen, J. J., de Baar, H. J. W., Follows, M., Harvey, M., Lancelot, C., Levasseur, M., Owens, N. P. J., Pollard, R., Rivkin, R. B., Sarmiento, J., Schoemann, V., Smetacek, V., Takeda, S., Tsuda, A., Turner, S., and Watson, A. J.: Mesoscale Iron Enrichment Experiments 1993-
2005: Synthesis and Future Directions, Science, 315, 612-617, doi:10.1126/science.1131669, 2007.

Breitbarth, E., Achterberg, E. P., Ardelan, M. V., Baker, A. R., Bucciarelli, E., Chever, F., Croot, P. L., Duggen, S., Gledhill, M., Hassellöv, M., Hassler, C., Hoffmann, L. J., Hunter, K. A., Hutchins, D. A., Ingri, J., Jickells, T., Lohan, M. C., Nielsdóttir, M. C., Sarthou, G., Schoemann, V., Trapp, J. M., Turner, D. R., and Ye, Y.: Iron biogeochemistry across marine systems progress from the past decade, Biogeosciences, 7, 1075-1097, 2010 , http://www.biogeosciences.net/7/1075/2010/.

Breitbarth, E., Gelting, J., Walve, J., Hoffmann, L. J., Turner, D. R., Hassellöv, M., and Ingri, J.: Dissolved iron (II) in the Baltic Sea surface water and implications for cyanobacterial bloom development, Biogeosciences, 6, 2397-2420, 2009, http://www.biogeosciences.net/6/2397/2009/.

Bruland, K. W., Rue, E. L., and Smith, G. J.: Iron and macronutrients in California coastal upwelling regimes: Implications for diatom blooms, Limnol. Oceanogr., 46, 1661-1674, 2001.

Caldeira, K. and Wickett, M. E.: Anthropogenic carbon and ocean pH, Nature, 425, 365-365, 2003.

Croot, P. L., Bowie, A. R., Frew, R. D., Maldonado, M. T., Hall, J. A., Safi, K. A., La Roche, J., Boyd, P. W., and Law, C. S.: Retention of dissolved iron and Fe-II in an iron induced Southern Ocean phytoplankton bloom, Geophys. Res. Lett., 28, 34253428, 2001.

Croot, P. L. and Laan, P.: Continuous shipboard determination of $\mathrm{Fe}(\mathrm{II})$ in polar waters using flow injection analysis with chemiluminescence detection, Anal. Chim. Acta, 466, 261-273, 2002.

Croot, P. L., Andersson, K., Öztürk, M., and Turner, D. R.: The distribution and speciation of iron along $6^{\circ} \mathrm{E}$ in the Southern Ocean, Deep Sea Res. II, 51, 2857-2879, 2004.

Croot, P. L., Frew, R. D., Sander, S., Hunter, K. A., Ellwood, M. J., Pickmere, S. E., Abraham, E. R., Law, C. S., Smith, M. J., and Boyd, P. W.: Physical mixing effects on iron biogeochemical cycling: FeCycle experiment, J. Geophys. Res.-Oceans, 112, C06015, doi:10.1029/2006JC003748, 2007.

Ehrhard, M. and Koeve, W.: Determination of particulate organic carbon and nitrogen, in: Methods of Seawater Analysis, edited by: Grasshoff, K., Kremling, K., and Ehrhard, M., Wiley-VCH, 437-444, 1999.

Engel, A., Zondervan, I., Aerts, K., Beaufort, L., Benthien, A., Chou, L., Delille, B., Gattuso, J. P., Harlay, J., Heemann, C., Hoffmann, L., Jacquet, S., Nejstgaard, J., Pizay, M. D., RochelleNewall, E., Schneider, U., Terbrueggen, A., and Riebesell, U.: Testing the direct effect of $\mathrm{CO}_{2}$ concentration on a bloom of the coccolithophorid Emiliania huxleyi in mesocosm experiments, Limnol. Oceanogr., 50, 493-507, 2005.

Fu, F.-X., Mulholland, M. R., Garcia, N. S., Beck, A., Bernhardt, P. W., Warner, M. E., Sañudo-Wilhelmy, S. A., and Hutchins, D. A.: Interactions between changing $p \mathrm{CO}_{2}, \mathrm{~N}_{2}$ fixation, and $\mathrm{Fe}$ limitation in the marine unicellular cyanobacterium Crocosphaera, Limnol. Oceanogr., 53, 2472-2484, 2008.

Gran, G.: Determination of the equivalence point in potentiometric titrations of seawater with hydrochloric acid, Oceanologica Acta, 5, 209-218, 1952.

Hansard, S. P., Landing, W. M., Measures, C. I., and Voelker, B. M.: Dissolved iron(II) in the Pacific Ocean: Measurements from the $\mathrm{PO} 2$ and $\mathrm{P} 16 \mathrm{~N}$ CLIVAR/CO2 repeat hy- 
drography expeditions, Deep Sea Res. I, 56, 1117-1129, doi:1110.1016/j.dsr.2009.1103.1006, 2009.

Hare, C. E., Leblanc, K., DiTullio, G. R., Kudela, R. M., Hutchins, D. A., Zhang, Y., Lee, P. A., and Riseman, S.: Consequences of increased temperature and $\mathrm{CO}_{2}$ for phytoplankton community structure in the Bering Sea, Mar. Ecol. Prog. Ser., 352, 9-16, 2008.

Heldal, M., Fagerbakke, K. M., Tuomi, P., and Bratbak, G.: Abundant populations of iron and manganese sequestering bacteria in coastal water, Aquat. Microb. Ecol., 11, 127-133, 1996.

Hopkinson, B. M. and Barbeau, K. A.: Organic and redox speciation of iron in the eastern tropical North Pacific suboxic zone, Mar. Chem., 106, 2-17, 2007.

Hutchins, D. A. and Bruland, K. W.: Grazer-mediated regeneration and assimilation of $\mathrm{Fe}, \mathrm{Zn}$ and $\mathrm{Mn}$ from planktonic prey, Mar. Ecol. Prog. Ser., 110, 259-269, 1994.

Hutchins, D. A. and Bruland, K. W.: Iron-limited diatom growth and $\mathrm{Si}: \mathrm{N}$ uptake ratios in a coastal upwelling regime, Nature, 393, 561-564, 1998.

Hutchins, D. A., Witter, A. E., Butler, A., and Luther III, G. W.: Competition among marine phytoplankton for different chelated iron species, Nature, 400, 858-861, 1999.

Jacobson, M. Z.: Studying ocean acidification with conservative, stable numerical schemes for nonequilibrium air-ocean exchange and ocean equilibrium chemistry, J. Geophys. Res.-Atmos., 110, D07302, doi:07310.01029/02004JD005220, 2005.

Johnson, K. M., Williams, P. J., Brandstrom, L., and Sieburth, J. M.: Coulometric total carbon analysis for marine studies: automation and calibration, Mar. Chem., 21, 117-133, 1987.

Johnson, K. S., Coale, K. H., Elrod, V. A., and Tindale, N. W.: Iron photochemistry in seawater from the equatorial Pacific, Mar. Chem., 46, 319-334, 1994.

King, D. W., Aldrich, R. A., and Charnecki, S. E.: Photochemical Redox Cycling of Iron in Nacl Solutions, Mar. Chem., 44, 105120, 1993.

Kuma, K., Nakabayashi, S., Suzuki, Y., Kudo, I., and Matsunaga, K.: Photo-Reduction of Fe (III) by Dissolved OrganicSubstances and Existence of Fe (II) in Seawater During Spring Blooms, Mar. Chem., 37, 15-27, 1992.

Kuma, K., Nishioka, J., and Matsunaga, K.: Controls on iron(III) hydroxide solubility in seawater: The influence of $\mathrm{pH}$ and natural organic chelators, Limnol. Oceanogr., 41, 396-407, 1996.

Lewis, B. L., Holt, P. D., Taylor, S. W., Wilhelm, S. W., Trick, C. G., Butler, A., and Luther III, G. W.: Voltammetric estimation of iron(III) thermodynamic stability constants for catecholate siderophores isolated from marine bacteria and cyanobacteria, Mar. Chem., 50, 179-188 1995.

Lewis, E. and Wallace, D. W. R.: Program Developed for $\mathrm{CO}_{2}$ System Calculations. ORNL/CDIAC-105. Carbon Dioxide Information Analysis Center, Oak Ridge National Laboratory, US Department of Energy, Oak Ridge, Tenessee, 1998.

Liu, X. W. and Millero, F. J.: The solubility of iron in seawater, Mar. Chem., 77, 43-54, 2002.

Maldonado M. T. and Price, N. M.: Reduction and transport of organically bound iron by Thalassiosira oceanica (Bacillariophyceae), J. Phycol., 37, 298-309, 2001.

Millero, F. J., Sotolongo, S., and Izaguirre, M.: The oxidation kinetics of Fe(II) in seawater, Geochim. Cosmochim. Acta, 51, 793$801,1987$.
Millero, F. J. and Sotolongo, S.: The oxidation of Fe(II) with $\mathrm{H} 2 \mathrm{O} 2$ in seawater, Geochim. Cosmochim. Acta, 53, 1867-1873, 1989.

Millero, F. J., Yao, W. S., and Aicher, J.: The Speciation of Fe(II) and Fe(III) in Natural-Waters, Mar. Chem., 50, 21-39, 1995.

Millero, F. J.: Solubility of Fe(III) in seawater, Earth Planet. Sci. Lett., 154, 323-329, 1998.

Millero, F. J., Woosley, R., Ditrolio, B., and Waters, J.: Effect of Ocean Acidification on the Speciation of Metals in Seawater, Oceanography, 22, 72-85, 2009.

Moffett, J. W., Goeffert, T. J., and Naqvi, S. W. A.: Reduced iron associated with secondary nitrite maxima in the Arabian Sea, Deep-Sea Res. I, 54, 1341-1349, 2007.

Öztürk, M., Steinnes, E., and Sakshaug, E.: Iron Speciation in the Trondheim Fjord from the Perspective of Iron Limitation for Phytoplankton, Estuarine, Coas. Shelf Sci., 55, 197-212, 2002.

Öztürk, M., Vadstein, O., and Sakshaug, E.: The effects of enhanced phytoplankton production on iron speciation and removal in mesocosm experiments in a landlocked basin of Hopavagen, Norway, Mar. Chem., 84, 3-17, 2003.

Öztürk, M., Croot, P. L., Bertilsson, S., Abrahamsson, K., Karlson, B., David, R., Fransson, A., and Sakshaug, E.: Iron enrichment and photoreduction of iron under UV and PAR in the presence of hydroxycarboxylic acid: implications for phytoplankton growth in the Southern Ocean, Deep Sea Res. II, 51, 2841-2856, 2004.

Pollard, R. T., Salter, I., Sanders, R. J., Lucas, M. I., Moore, C. M., Mills, R. A., Statham, P. J., Allen, J. T., Baker, A. R., Bakker, D. C. E., Charette, M. A., Fielding, S., Fones, G. R., French, M., Hickman, A. E., Holland, R. J., Hughes, J. A., Jickells, T. D., Lampitt, R. S., Morris, P. J., Nedelec, F. H., Nielsdottir, M., Planquette, H., Popova, E. E., Poulton, A. J., Read, J. F., Seeyave, S., Smith, T., Stinchcombe, M., Taylor, S., Thomalla, S., Venables, H. J., Williamson, R., and Zubkov, M. V.: Southern Ocean deep-water carbon export enhanced by natural iron fertilization, Nature, 457, 577-580, 2009.

Riebesell, U.: Effects of CO2 enrichment on marine phytoplankton, J. Oceanogr., 60, 719-729, 2004.

Riebesell, U., Schulz, K. G., Bellerby, R. G. J., Botros, M., Fritsche, P., Meyerhofer, M., Neill, C., Nondal, G., Oschlies, A., Wohlers, J., and Zollner, E.: Enhanced biological carbon consumption in a high $\mathrm{CO}_{2}$ ocean, Nature, 450, 545-548, doi:10.1038/nature06267, 2007.

Rijkenberg, M. J. A., Fischer, A. C., Kroon, J. J., Gerringa, L. J. A., Timmermans, K. R., Wolterbeek, H. T., and de Baar, H. J. W.: The influence of UV irradiation on the photoreduction of iron in the Southern Ocean, Mar. Chem., 93, 119-129, 2005.

Roy, E. G., Wells, M. L., and King, D. W.: Persistence of iron(II) in surface waters of the western subarctic Pacific, Limnol. Oceanogr., 53, 89-98, 2008.

Rue, E. L. and Bruland, K. W.: Complexation of iron(III) by natural organic ligands in the Central North Pacific as determined by a new competitive ligand equilibration/adsorptive cathodic stripping voltammetric method, Mar. Chem., 50, 117-138, 1995.

Rue, E. L. and Bruland, K. W.: The role of organic complexation on ambient iron chemistry in the equatorial Pacific Ocean and the response of a mesoscale iron addition experiment, Limnol. Oceanogr., 42, 901-910, 1997.

Santana-Casiano, J. M., Gonzalez-Davila, M., and Millero, F. J.: Oxidation of Nanomolar Levels of Fe(II) with Oxygen in Natural Waters, Environ. Sci. Technol., 39, 2073-2079, 2005. 
Santana-Casiano, J. M., Gonzalez-Davila, M., and Millero, F. J.: The role of $\mathrm{Fe}(\mathrm{II})$ species on the oxidation of $\mathrm{Fe}(\mathrm{II})$ in natural waters in the presence of $\mathrm{O}_{2}$ and $\mathrm{H}_{2} \mathrm{O}_{2}$, Mar. Chem., 99, 70-82, 2006.

Sarthou, G., Timmermans, K. R., Blain, S., and Treguer, P.: Growth physiology and fate of diatoms in the ocean: a review, J. Sea Res., 53, 25-42, 2005.

Schulz, K. G., Riebesell, U., Bellerby, R. G. J., Biswas, H., Meyerhöfer, M., Müller, M. N., Egge, J. K., Nejstgaard, J. C., Neill, C., Wohlers, J., and Zöllner, E.: Build-up and decline of organic matter during PeECE III, Biogeosciences, 5, 707-718, 2008, http://www.biogeosciences.net/5/707/2008/.

Shaked, Y., Kustka, A. B., Morel, F. M. M., and Erel, Y.: Simultaneous determination of iron reduction and uptake by phytoplankton, Limnol. Oceanogr.-Methods, 2, 137-145, 2004.
Sunda, W. and Huntsman, S.: Effect of $\mathrm{pH}$, light, and temperature on Fe-EDTA chelation and Fe hydrolysis in seawater, Mar. Chem., 84, 35-47, 2003.

Ussher, S. J., Worsfold, P. J., Achterberg, E. P., Laes, A., Blain, S., Laan, P., and de Baar, H. J. W.: Distribution and redox speciation of dissolved iron on the European continental margin, Limnol. Oceanogr., 52, 2530-2539, 2007.

Watson, A. J., Bakker, D. C. E., Ridgwell, A. J., Boyd, P. W., and Law, C. S.: Effect of iron supply on Southern Ocean $\mathrm{CO}_{2}$ uptake and implications for glacial atmospheric $\mathrm{CO}_{2}$, Nature, 407, 730733, 2000.

Wells, M. L. and Mayer, L. M.: The Photoconversion of Colloidal Iron Oxyhydroxides in Seawater, Deep-Sea Res. I, 38, 13791395, 1991. 